\title{
Knowledge Space Concept and Its Application for Servitizing Manufacturing Industry
}

\author{
H. M. Belal, Kunio Shirahada, Michitaka Kosaka
}

School of Knowledge Science, Japan Advanced Institute of Science and Technology, Nomi, Japan.

Email: kosa@jaist.ac.jp

Received April 2 ${ }^{\text {nd }}, 2012$; revised April 20 ${ }^{\text {th }}, 2012$; accepted May 2 ${ }^{\text {nd }}, 2012$

\begin{abstract}
A new model for servitization of the manufacturing industry is proposed based on the concept of knowledge space, denotes that the set of all knowledge from performing companies, customers, and users is dynamic over time and has a positive relationship with the produced solution. This research explains the use of the knowledge space concept for value co-creation in the manufacturing industry. It also discusses the pertinent issues of the value co-creation process for adapting servitization based on the results of one "B to B to B" collaboration and two "B to B to C" collaboration case studies.
\end{abstract}

Keywords: Knowledge Space; Servitization; Design Process; Value Co-Creation; Company Transformation; Integration

\section{Introduction}

A service is an economic activity that creates value and provides benefits for a customer at specific times and places by bringing about a desired change in, or on behalf of, the recipient of the service [1]. A service is also the application of specialized competences (knowledge and skill) through deeds, processes, and performances for the benefit of another entity or the entity itself [2]. From this declaration, individuals can obtain a clear perspective of trade and industry phenomena, by engage of value. Value is co-created through the mutual effort of firms, employees, customers, stakeholders, government agencies, and other entities related to any given exchange [3, 4]. Therefore, the customer-manufacturer contact point plays an important role for value co-creation [5]. The world is becoming more oriented toward services; the escalation of services is one of the key trends witnessed in recent years. The majority of the national gross domestic product (GDP) of developed economies is also driven by the service sector [6]. Under these circumstances, pure manufacturing in developed economies is under massive pressure [7]. Thus, manufacturing in developed economies needs to move up the value chain and compete on the basis of value delivered rather than on the basis of cost [8].

Western economies have already started to sustain themselves on the basis of value delivered by shifting their market share from manufacturing to more product- service-oriented systems $[9,10]$. This value chain concept was first introduced by Vandermerwe and Rada [11], who coined it as the strategy of servitization in business. However, the adaption of servitization and its implementtation by a typical manufacturing firm is very difficult. It requires re-design of the organizational philosophy and needs to improve performing capacity [12] through successfully managing the interaction of business, people, and technology [13]. Wise and Baumgartner [14], Oliva and Kallenberg [15], and Weeks [16] claimed that to adapt a successful servitization strategy, organizations are likely to change their strategies, operations and value chains, technologies, people expertise supporting cultural shifts in the organizational blueprint, and system integration capabilities. Bititci and Martinez [17], and Bastl [18] strongly recommended that companies maintain a constant flow of innovation, not only in terms of what is offered to the customer, but also in how products and services are designed, produced, delivered, and marketed. Therefore, when engineers who design products try to design services, they encounter difficulties such as a lack of organizational resources. Thus, the transition from a product-centric vision to a combined productservice-centric or customer-centric vision is still poorly understood and remains a new and complex concept [1922].

Researchers have discussed the general idea of servitization and provided valuable ideas on opportunities [5] for a pure manufacturing company to engage in product- 
based service-oriented business, but there is no actual journey process for achieving those opportunities. Again there is much significant literature and theoretical discussion available in the general field of strategic organizational change, but there are no models specific to the issue of servitization as a change process [23].

Therefore, this work aims to present a view of the value co-creation process in the knowledge space concept and realization of it for servitization. It also aims to develop a model that elucidates the ideas for continuous value co-creation by integrating "B to B to C", which produces a company as a value provider. The rest of the paper is structured as follows. Section 2 reviews the literature on servitization in the manufacturing industry. Section 3 describes the concept of knowledge space and the value co-creation process, this section also describes a collaboration model for servitization in the manufacturing industry. Section 4 verifies and analyzes real-life cases with regard to adapting a servitization strategy, and the final section concludes the paper with a summary.

\section{Literature Review of Servitization in Manufacturing Industry}

Manufacturers generally offer services as a way to protect their products rather than as the basis of their competitive strategy. However, the strength of service activeties within the manufacturing industry, namely servitization, has become a main source of competitive advantages. This is recognized as an important research area in the service science field, and authors have discussed the main origins of servitization, i.e., economics.

Manufacturing firms in developed economies cannot compete on the basis of cost [10]. Van Looy, Van Dierdonck, and Gemme [23] explained that a customer may require a value-creating process with a product (e.g., driving), but does not require the product itself (e.g., a car), so a servitization strategy is require for such a customer. They also discussed strategic advantages, another core root where servitization helps to differentiate products through product-based services. Services can provide continuing value and revenue through the life cycle of products (i.e., proactive maintenance by remote monitoring). Mont [24] has shown that servitization is needed for environmental benefits, although a criticism by Teece [25] is that generally this unique strategy is not easily recognized. However, the term "servitization" was introduced by Vandermerwe and Rada more than 20 years ago, where they argued that modern corporations were increasingly offering fuller market packages or bundles of customer-focused combinations of goods, services, support, self-service, and knowledge. They also noted that increasing numbers of corporations throughout the world were adding value to their core corporate offerings through services. Oliva and Kallenber [15] also presented this change, in which a manufacturing firm moves away from recognizing services as add-ons to its physical goods towards viewing goods as add-ons to their core services. The servitization practice naturally assumes an increase in the volume of provided services as well as a broadening of the coverage of the services purchased by a single customer [26]. This practice also requires changes in the relationship between the customer and the provider to create mutual value $[5,7,27,28]$. Thus, the most important factor for the journey of servitization is to move towards customer centricity from physical-goods centricity, which means offering customers more tailored and integrated solutions instead of plain products [9] as final solutions determined by the customers, and excelling simultaneously in both the goods and services dimensions of the servitization continuum [28]. In other words, both a transfer from the old transaction-based mode of service to continuous connection with the customer and a shift towards process-oriented services for end-users instead of physical goods efficacy is required [15].

Therefore, the fundamental movement of the manufacturing industry to offering services and goods together in single "value packages" [14] to their customers and the move to a tightly coupled combination of products and services is known as servitization [11]. That is, servitization is the transition process of an organization that promised continuous service value co-creation with its product through association between the customer and manufacturer, which in the end signifies a firm as the value provider and fulfills the needs of clients.

\section{Knowledge Space Concept and Value Co-Creation Model in Manufacturing Industry}

\subsection{Knowledge Space Concept}

The knowledge space theory was derived in 1985 by Jean-Paul Doignon and Jean-Claude Falmagne, and this perception explains the formation of a given province of knowledge. The formal concept is that a field of knowledge is specified by a finite set of items, i.e., problems or tasks a student may or may not be able to solve. Each student can or tries to solve it from his or her knowledge state. The solution could be either correct or incorrect, but the set of all possible knowledge states is called a knowledge space.

From the business viewpoint, Kosaka [29] appealed that the "knowledge space (all knowledge from providers-recipients) is dynamic, and it has a fundamental optimistic relationship with a solution". In recent years, it has become practical for organizations to modify their business philosophy from product-centric to customercentric. In this vision, a company follows the value or 
solution that required by the customer and has to provide that solution. Thus, novel knowledge is a pre-requirement by which a company can perform reasonably to translate its innovative philosophy into action as well as ensure a likely solution for the customer. Under these circumstances, the company needs to gather or seek further knowledge, which is why collaborating with ideal partners is a necessity for the host company. This collaboration creates a font of collected novel knowledge or experience from alliance partners (i.e., guest companies, idea makers, and customers). The obtained knowledge will be added to the current knowledge of the host company, and the combined competence of knowledge will produce the required solution as well as co-create value. Thus, all the knowledge of the host company and guest companies, idea makers, and customers enriches the knowledge space (as shown in Figure 1) by which the company becomes able to deliver a valuable solution and satisfy the customer.

\subsection{Value Co-Creation Process}

The creation of value is currently the core challenge for the manufacturing industry. The concept of value cocreation is explored by Vargo and Lusch [2] in their service dominant (S-D) logic, with the basic view that the service is the common denominator in an exchange and not a special form of exchange. Their developed notion discusses the value-creation process that occurs when a customer consumes, or uses, a product or service, rather than when the output is manufactured. It also argued the importance of the value-creating processes that involve the customer as a co-creator of value [30]. In other words, the idea is that the roles of producers and consumers are not distinct [4] where value is always co-created jointly and reciprocally, in the interaction among providers and beneficiaries through integration of resources and application of competencies [3].

The provider normally produces a tangible product or service, but the complexity of world business dynamics,

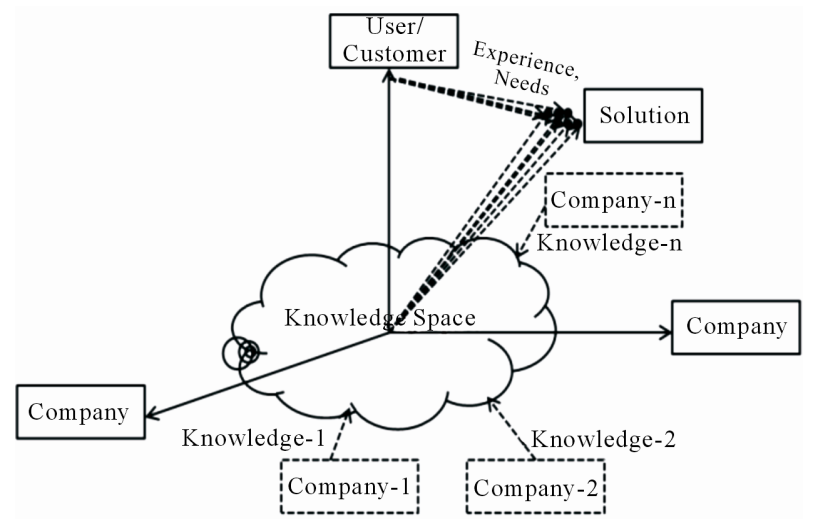

Figure 1. N-dimensions knowledge space. fluidity of the market [31], customer behaviors [31], demands, and expectations have changed over time. Today, customers are involved in dialog or experience-knowledge sharing with the provider at each stage of product manufacturing and product delivery. This form of dialog should be seen as an interactive process of learning together. Thus, Lusch and Vargo [30] determined that the co-creation of value is a desirable goal because it can assist firms in highlighting the customer's or consumer's viewpoint and in improving the front-end process of identifying customers' needs and wants.

Therefore, in the value co-creation process, customers are valuable "resources" and participating as co-producers in production [32], while co-production is now a standard characteristic from the unique service perspective and an important characteristic in manufacturing. Customers actively share their experience, knowledge, and needs with the company, and the company gathers this information to develop a new solution. In this process, the company may also collaborate with other partners, to increase its existing performance capability in order to meet customer expectations, fabricate a service [33], and deliver something of value. This current trend for companies highlights the issues of value-in-use as well as value from the economic exchange where the manufacturer and customer co-create mutual value, which is obtained by the customer at the end of the process. Thus, customers have responsibilities to ensure co-design and co-specification of a product and the successful delivery of services, e.g., "Nike + iPod Sport Kit” or "HeatTech clothing”, that can create continuous value for users.

\subsection{Value Co-Creation in Manufacturing Industry from Viewpoint of Knowledge Space}

Value co-creation is a strategic weapon and ongoing concern in building and sustaining reasonable benefits [5] for both the provider and receiver. From the perspective of the manufacturing industry, the revenue from service businesses tends to be steadier than that from only sales of manufactured goods [33]. The company can no longer act separately [34] without connecting to its customer, user, or other unit, as the company needs to understand what customer or user value means [7], as well as what value is currently required by the customer. Understanding this is important for designing, delivering, and creating value. Thus, staying in touch with the customer is necessary for the company, since the solutions that are needed are determined by the customers. Moreover, the customer's needs, expectations, demands, and experience vary according to the time, situation, and conditions, so the company has to create an unbroken link with customers to stay updated on the customer's expected solu- 
tions. Without this link, the company will be unable to remain competitive in the market.

The knowledge space helps the manufacturing company maintain continuous value co-creation with users/ customers. In this concept, the company will constantly gather knowledge (experience, competencies, needs, etc.) from coalition associates, customers, users, government agencies, and other entities that will increase its ability to offer or create a proper solution meeting the customer requirements. For example, Nike is a very traditional manufacturing company that applies its knowledge, skills, and capabilities to transform raw materials into running shoes. However, when the company determined to adapt a servitization strategy, or when it wanted to move to a value chain vision, it planned to create an endless link with the customer for collecting update data as well as transferring value. Accordingly, it made an alliance with Apple to share Apple's know-how and experience for value creation, and Nike provided its advanced technology. Finally, through the combination of knowledge and technology from Nike, Apple, and their customers, the "Nike + iPod Sport Kit" has emerged as an original solution that co-creates users' value.

\subsection{Collaboration Model for Servitization in Manufacturing Industry}

Most manufacturers have learned all kinds of ways to satisfy customers. Changing their viewpoint according to the customer's needs has required companies to react by developing new operations systems for delivering original solutions that will secure market shares and acquire customers as well as retain them. In this case, companies have realized that they must stay connected with their working partners to amplify their strengths and competencies. At the same time, creating an endless link with the customer is essential to respond effectively and efficiently to their requirements as well as co-create value. Thus, manufacturing companies look to activities that increase services to shift the standing from being a "typical goods seller" towards being a "value provider". However, this shifting process is an immense challenge, as the organization was planned to offer only traditional goods, but it now wishes to offer a total value package. This is a completely different way of thinking for the organization, and thus, the company needs to build an effective value design process that is able to produce as well as offering a value package rather than a typical product. The present design process is product-centric-oriented, but to adapt to servitization, the company needs to focus on a customer-demand-oriented design process. Baines [9] and Nelly [10] stated that for a total value offering, the company must extend its existing capabilities and processes to form a common value, while every resource is needed to sustain this. Under these circumstances, firms must always remain in a dynamic-capability building mode, retaining their capacity to renew their resources. However, this shifting process is an immense challenge, as the organization was planned to offer only traditional goods, but it now wishes to offer a total value package. This is a completely different way of thinking for the organization, and thus, the company needs to build an effective value design process that is able to produce as well as offering a value package rather than a typical product, same time by the mentioned design process the company can become competent to enhance [25] of categorize the lack of significant resources, which will help them to create continuous value as well as adapt to servitization.

Therefore, a manufacturing company needs to fit in the knowledge space concept by collaborating with another company and customer, which can be call a " $\mathrm{B}$ to $\mathrm{B}$ to C” collaboration (as shown in Figure 2). In this process, the "host company (A)" first integrates with the "guest company (B)," and then they share their knowledge (core strengths) to make the "new company (C)," or extend their business line with a servitized vision. This new business line is rich with the full capability to meet customer demands. This process also creates a link with the customer for sharing or gathering updated experience, knowledge, needs, and demands of the customer, so this connection helps to create mutual value without interruption as well as adapt to servitization.

\section{Case Study 1: "B to B to B"-Energy Saving Service Business Using Inverter}

\subsection{Hitachi Capital and HDRIVE Case}

Purpose: To arise and co-create value with partners through not only from an economic perspective but also by giving proper consideration to the environment and society that make sure to achieve sustainable growth.

HDRIVE: HDRIVE is highly praised, new type and outstanding energy-service business, under Hitachi, Ltd. The company principally offers its clients' production plants with such equipment as high-pressure inverters

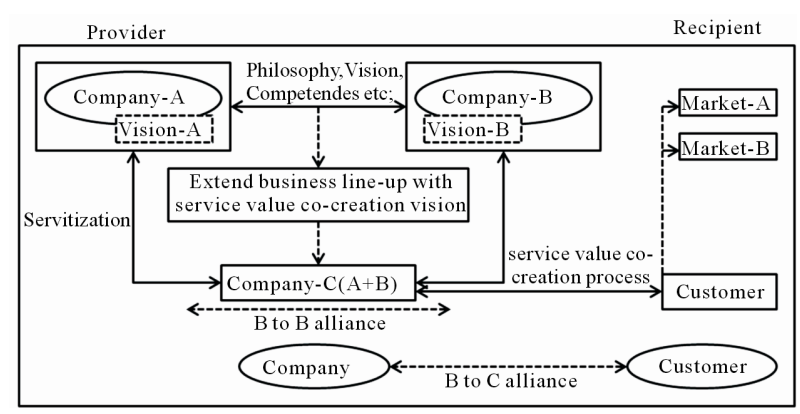

Figure 2. "B to B" and "B to C" collaboration model. 
and highly effectual motors with no charge.

Hitachi Capital: The Hitachi Capital is well trusted by customers, local community and Society as well. The company is manufacturer-affiliated financial services company. It is committed to providing financial support to their customer that focuses on products. It also building a trusty relationship with stakeholders and creating service value.

Principle of Energy saving service system: The energy saving service business; HDRIVE [36] is successful business model for servitizing the manufacturing Industry. This service business shares profits of saved energy with inverters between recipients and service providers. However, there are various heavy industries, e.g., the steel industry and oil industry, that use many motors, and energy consumption is an important issue affecting their costs and $\mathrm{CO}_{2}$ emissions. The energy consumed by motors can be reduced by using inverters, as shown in Figure 3.

The "amount of saved energy $\mathbf{S}$ " in the figure is calculated by referring to the "electric utility curve of motor a" and the "ratio of saved energy $\mathbf{b}$," which depends on the operation ratio $X_{1}, X_{2}$, and $X_{3}$. Saving energy makes a profit, and this profit can be shared by the customers (others company, i.e. steel or oil industry), service provider (HDRIVE), and financial company (Hitachi Capital) who make the initial investments in the inverters, as shown in Figure 4.

By using this business model, customers need no initial investment to buy inverters because the cost is borne by the financial company, and payments to the financial company are based on profits from the reduced energy costs.

In this service business, service providers set up inverters and monitoring systems for collecting operation data and calculating the profit due to energy savings, as shown in Figure 5.

\subsection{Knowledge Space and Integration}

This case demonstrates the "B to B to B" integration and co-creates value through implementing the knowledge space concept with business partners. The high-volume pure manufacturing industry, including steel or oil companies, service provider (HDRIVE), and financial company (Hitachi Capital), inputs its knowledge or core competencies to reduce energy consumption.

Here, the pure manufacturing industry is acting as a customer with the demand of energy saving. Therefore, the service provider and financial company collaborate with each other and allocate their inverter, information, network technology, know-how of monitoring systems, experience, and economic and risk management to create as well as deliver an appropriate solution to the customer.

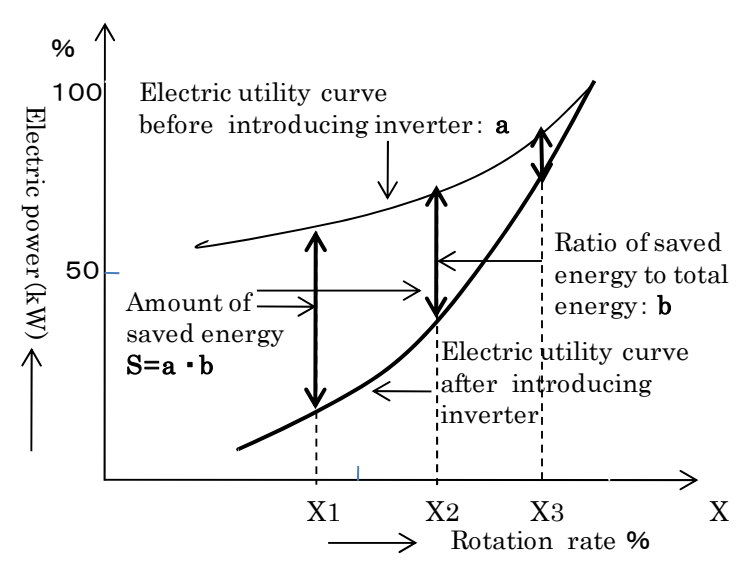

Figure 3. Energy saving using inverter [36].

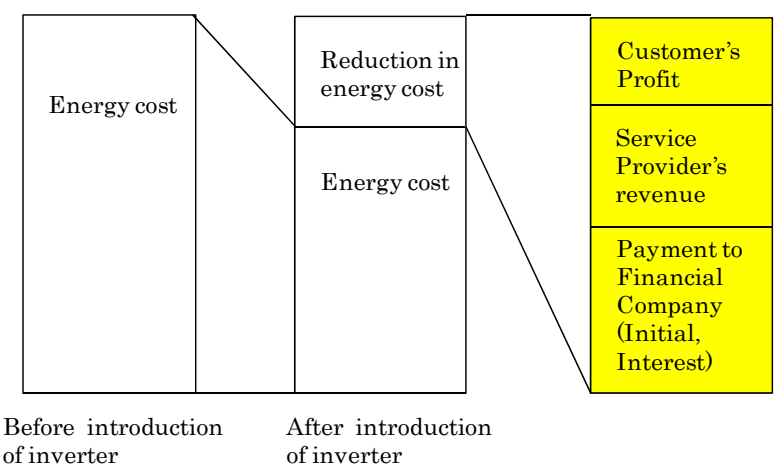

Figure 4. Profit sharing framework in HDRIVE [35].

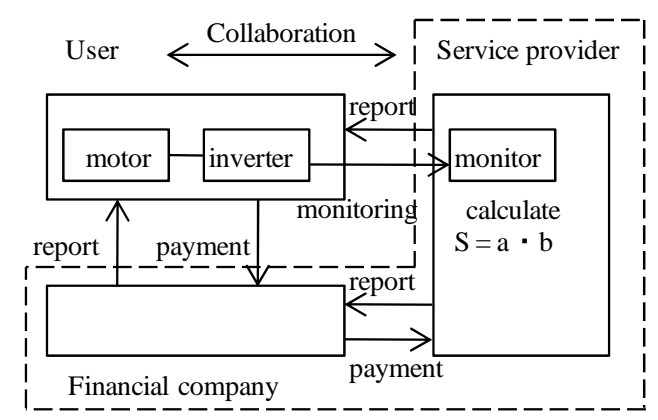

Figure 5. Data collection \& profit calculation [35].

Thus, all the knowledge, i.e., from the manufacturing company-experience, needs, expectation (knowledge-1); from the service provider-advance technology and know -how (knowledge-2); and from the financial company - economic and risk management (knowledge-3), is combined, increasing the capability to meet customer expectations and co-create continuous value.

\section{Case Study 2: "B to B to C" (Table 1)}

\subsection{Nike and Apple Case [36]}

Purpose: This case was chosen with the aim of expressing how manufacturing firms can move to the value 
chain viewpoint in order to gain competitive advantages by sharing their competencies and by co-creating experiences and needs of value with users.

Company background (Nike): Nike, Inc. is a worldleading sportswear and fashion wear manufacturing company established in 1964 at the University of Oregon. It launched its own line known simply as "Nike" in 1971. This company is famous for its "Just Do It" slogan and Swoosh logo trademark, and by 1990 it had obtained value as a prestigious brand in the world. The company always promised to meet the expectations of all types of athletes. In 2000, in conjunction with the Sydney Olympics, the company launched Nike Shox shoes. This shoe had 15 years' worth of research behind it. Nowadays, Nike is eager to promote its image as a total service provider rather than only a typical product provider. Nike + is touted as the "world's largest running club", where all users can connect with Nike to receive better service. Currently, Nike is the largest manufacturer and supplier that operates in over 160 countries worldwide.

Company background (Apple): Apple Inc. is a USbased multinational corporation that is well known for its innovation in electronics. The company mainly offers consumer electronics, computer software, and comercial servers. It was founded in April 1976 by Steve Jobs and Steve Wozniak. Apple became a high-value innovation manufacturing company through the drive of its CEO, Steve Jobs. He brought with him a new corporate philosophy of recognizable products and simple design that created and delivered real value to the customer. Currently, Apple is the largest technology-based firm in the world.

Nike and Apple collaboration: Steve Jobs, the CEO of Apple, and Mike Parker, the CEO of Nike, announced a partnership between their two organizations named Nike + iPod on 23 May 2006. This business alliance aimed to launch innovative products with the campaign slogan of "Tune your run” (Apple-Press Release, 23/05 /2006).

Steve Jobs announced that "the company decided to work with Nike in order to elevate together music and sport to a new level of performance”. Mike Parker stated that Nike + iPod resulted from forming a partnership between two global brands that had a mutual passion, i.e., the creation of products or services that enable the user to enjoy new experiences full of innovation and design, as well as an effective change in the way people perceive and do sport”. Thus, in this corporate alliance between Nike and Apple, the goal was to co-create users' value that could satisfy stakeholders as well as help to gain competitive advantages for both parties.

Nike and Apple share their competencies and strengths in the aim to develop a new product (solution) that connects music and physical exercise. Apple provides its know-how and experience (electronic equipment, players, and digital music) and Nike provides its advanced technology and design of running shoes; again same time the users (idea makers Steve Jobs and Mike Parker) allocate their experience, needs, knowledge, and so on. Through the combination of this knowledge and technology, the "Nike + iPod Sport Kit" has emerged as a novel solution that co-creates users' value.

"Nike + iPod Sport Kit" is designed with a sensor and a receiver for the iPod nano player. The wireless sensor communicates with the receiver and works exclusively with Nike + shoes and the iPod nano to provide real-time feedback about individual performance during training. Users can select their form of exercise from a personal training list. This automatic sensor is very sensitive to be able to provide the information about foot movement, rhythm, distance covered, time, and calories burned.

Nike + consumers can become members of the global Nike + community, linking consumers all over the world, and in this way users can receive feedback on their activities individually or together with other members in any part of the world. The user will automatically connect to the nikeplus.com site when the receiver is connected to a computer from the iPod. The "Nike + iPod Sport Kit" is the main reason for this community's success (Hispanic PR Wire-Press Release, 03/04/2008) and for the sharing and creating of value. For Nike, in the past, the product was the end point of the consumer experience, and now it is the starting point, and it serves continuous value to customers.

\subsection{Uniqlo-Toray Case $[37,38]$}

Purpose: The strategic partnership between Uniqlo and Toray was formed to offer new value products to both firms' customers through allocation of resources and utilization of the experiences of users.

Company background (Uniqlo): Fast Retailing opened the first Uniqlo shop on November 1, 2005. It offered casual clothing to customers. Uniqlo is Japan's leading clothing retail chain in both sales and profits. The company's key philosophy is to offer well-made, affordable and fashionable clothing at a low price. The company has recently aimed to acquire the highly brand-conscious consumer group by offering fashion clothing. Uniqlo has more than 680 stores across Japan, China, and the UK. It plans to expand into the USA and also wants to improve its brand value.

Company background (Toray): Toray Industries, Inc. is one of Japan's largest fiber producers. It started in the 1920s as two large rayon manufacturing companies: Teikoku Jinzo Kenshi Ltd and Asahi Kenshoku Ltd. The company operates over 200 subsidiaries and affiliates. The core production of Toray is fibers and textiles, plastics 
Table 1. Integration, knowledge space, and result through partnership.

\begin{tabular}{|c|c|c|c|c|}
\hline Integration & User's requirements (C) & $\begin{array}{l}\text { Host Company's } \\
\text { knowledge (B) }\end{array}$ & $\begin{array}{l}\text { Guest Company's } \\
\text { knowledge (B) }\end{array}$ & Value co-creation \\
\hline B-B-C & Value package & Technology/know-how & Technology/know-how & Value co-creation process \\
\hline Nike \& Apple & $\begin{array}{l}\text { Together sports, trainee } \\
\text { colleague and music }\end{array}$ & $\begin{array}{l}\text { Advance technology and } \\
\text { customers }\end{array}$ & $\begin{array}{l}\text { Know-how, experience \& } \\
\text { digital technology }\end{array}$ & 'Nike+ipod sport kit \\
\hline Uniqlo \& Toray & $\begin{array}{l}\text { Healthy,environmental } \\
\text { friendliness \& comfort clothing }\end{array}$ & $\begin{array}{l}\text { Know-how, skill \& } \\
\text { customers }\end{array}$ & $\begin{array}{l}\text { World-best materials \& } \\
\text { technology }\end{array}$ & Heat-Tech clothing \\
\hline Using Resources & Ideas, needs, experience & $\begin{array}{l}\text { Nike: Advanced technology } \\
\text { Uniqlo: know-how }\end{array}$ & $\begin{array}{l}\text { Apple: Know-how, experience } \\
\text { Toray: Materials, technology }\end{array}$ & $\begin{array}{l}\text { Solution determined } \\
\text { by users }\end{array}$ \\
\hline
\end{tabular}

and chemicals, films and resins, housing and engineering products, circuit materials used in information technology-related products, and a host of various other products ranging from artificial kidneys and catheters to contact lenses.

The vision of this company is to create new value through innovative ideas, technologies, and products, and the mission is to deliver new value to customers through high-quality products and superior services. The company believes in strategic management to form long-term relationships with internal as well as external stakeholders. At present, Toray generates business throughout Asia, Europe, and North and South America and plays a significant role in the world economy.

Uniqlo-Toray strategic partnership: At a press conference on 19 June 2006, Uniqlo and Toray declared their intention to work together closely and enthusiastically on new product development and planning. This alliance aims to create a seamless product development system that unifies all the stages from material selection through the final product sale, and then it looks to develop a new, groundbreaking material for the market. This collaboration has led to the creation of completely new and inspired products, and generated fresh customer demand for better clothes to enrich their lives.

Both companies' idea makers designed the new projects based on concepts of healthy beauty, ecology, function and comfort, and innovation. Moreover, the idea makers also worked on creating a new unique distribution structure for continuous connection with customers, as they considered it necessary according to current market demand, where Toray's advanced materials and technology performed a vital role with Uniqlo's knowhow and skill. Thus, through this combination of both parties' strengths, "Heat-Tech clothing” was produced, satisfying customers as well as adding value to gain competitive advantages.

This "Heat-Tech clothing" promised to deliver heat generation, heat retention, soft texture, odor control, stretchable comfort, anti-static, and non-deforming properties. The fabric is woven from a specially designed hollow fiber thread that traps pockets of warm air, insu- lating the body in the same way a heavier fiber would but without the bulk. Milk proteins containing natural amino acids are added to the fibers to create a soft, smooth feel. Heat-Tech fabric also includes a mix of rayon, a manmade fiber created from cellulose, to turn the body's perspiration into heat. Therefore, Heat-Tech clothing delivers a total value package rather than a product only, signifying that Uniqlo-Toray is a value provider.

\section{Conclusion}

Servitization is a core strategy in the modern movement in business by which the manufacturing industry can gain competitive advantages, but the journey to servitization is difficult for a pure manufacturing company. This study was conducted in response to the current lack of a true process for adapting to servitization through developing a collaboration model among "B to B to C" parties, based on the knowledge space concept. The alliance of "B to B" improves the companies' current performance capability through sharing their knowledge and other resources, and then that combined knowledge is connected with the users/customers' experience, needs, and knowledge to make the " $\mathrm{B}$ to $\mathrm{C}$ " collaboration. All the knowledge of the performing companies and customers ensures delivery of an effective solution according to the customer's expectation. Therefore, the developed model explains how a manufacturing firm can achieve servitization and sustain competitive advantages by " $\mathrm{B}$ to $\mathrm{B}$ " and " $\mathrm{B}$ to $\mathrm{C}$ ” integration based on the knowledge space notion. Moreover, this research has presented three real-life case studies, where the case companies are actually successful through sharing their technology, knowledge, and other resources. The collaboration experiences of these companies has helped to clarify how an effective process can enable a manufacturer to create a new solution for the customer and how a company can move from the traditional product-centric to value-chain perspective.

\section{REFERENCES}

[1] C. Lovelock and J. Writez, "Service Marketing-People, Technology, Strategy, 5/e,” Pearson Prentice Hall, Upper 
Saddle River, 2004.

[2] S. L. Vargo and R. L. Lusch, "Evolving to a New Dominant Logic for Marketing,” Journal of Marketing, Vol. 68, No. 1, 2004, pp. 1-17. doi:10.1509/jmkg.68.1.1.24036

[3] S. L. Vargo, P. P. Maglio and M. A. Akaka, "On Value and Value Co-Creation: A Service Systems and Service Logic Perspective,” European Management Journal, Vol. 26, No. 3, 2008, pp. 145-152. doi:10.1016/j.emj.2008.04.003

[4] Stephen L. Vargo and Robert F. Lusch, "Service-Dominant Logic: Continuing the Evolution," Journal of the Academy of Marketing Science, Vol. 36, No. 1, 2008, pp. 1-10. doi:10.1007/s11747-007-0069-6

[5] N. Uchihira, Y. Kyoya , S. K. Kim, K. Maeda, M. Ozawal and K. Ishii, "Analysis and Design Methodology for Recognizing Opportunities and Difficulties for Product-Based Services," Portland International Center for Management of Engineering and Technology, Portland, 5-9 August 2007, pp. 2755-2762. doi:10.1109/PICMET.2007.4349613

[6] D. M. Elche and Á. González, "Influence of Innovation on Performance: Analysis of Spanish Service Firms," The Service Industries Journal, Vol. 28, No. 10, 2008, pp. 1483-1499. doi:10.1080/02642060802250294

[7] A. Neely, "The Servitization of Manufacturing: An Analysis of Global Trends," 14th European Operations Management Association Conference, 17-19 June 2007, pp. 110.

[8] M. E. Porter and C. H. M. Ketels, "UK Competitiveness: Moving to the Next Stage," Economic and Social Research Council, Swindon, 2003.

[9] T. Baines, H. Lightfoot, S. Evans and A. Neely, "Stateof-the-Art in Product Service Systems," Journal of Engineering Manufacture, Vol. 221, No. 10, 2007, pp. 15431551. doi:10.1243/09544054JEM858

[10] A. Neely, "Exploring the Financial Consequences of the Servitization of Manufacturing,” Journal Operations Management Research, Vol. 1, No. 2, 2008, pp. 103-118. doi:10.1007/s12063-009-0015-5

[11] S. Vandermerwe and J. Rada, "Servitization of Business: Adding Value by Adding Services,” European Management Journal, Vol. 6, No. 4, 1988, pp. 314-324. doi:10.1016/0263-2373(88)90033-3

[12] R. Werner and W. Ulaga, "How to Sell Services More Profitably,” Harvard Business Review, Vol. 86, No. 5, 2008, pp. 90-96.

[13] T. U. Daim, A. Jetter and H. Demirkan, "Perspective: Technology Management in the Service Sector,” International Journal of Services Technology and Management, Vol. 13, No. 1-2, 2010, pp. 3-16. doi:10.1504/IJSTM.2010.029668

[14] R. Wise and P. Baumgartner, "Go Downstream: The New Profit Imperative in Manufacturing," Harvard Business Review, Vol. 77, No. 5, 1999, pp. 133-141.

[15] R. Oliva and R. Kallenberg, "Managing the Transition from Products to Services," International Journal of Service Industry Management, Vol. 14, No. 2, 2003, pp. 160172. doi:10.1108/09564230310474138
[16] R. Weeks, "The Culture and Skill Challenges Associated with Servitization; A South African Perspective,” Journal of Contemporary Management, Vol. 7, 2010, pp. 110-128.

[17] U. S. Bititci and V. Martinez, "Creating and Sustaining Competitive Advantage in Collaborative Systems: The What and the How," Production Planning \& Control, Vol. 14, No. 5, 2003, pp. 410-424. doi:10.1080/0953728032000112331

[18] V. Martinez and M. Bastl, "Challenges in Transformin Manufacturing Organisations into Product-Service Prviders,” Journal of Manufacturing Technology Maagement, Vol. 21, No. 4, 2010, pp. 449-469. doi:10.1108/17410381011046571

[19] C. A. Voss, "Alternative Paradigms for Manufacturing Strategy," International Journal of Operations \& Production Management, Vol. 25 No. 2, 2005, pp. 12111222. doi:10.1108/01443570510633611

[20] R. Johnston, "Operations: From Factory to Service Man Agement,” International Journal of Service Industry Management, Vol. 5, No. 1, 1994, pp. 49-63. doi:10.1108/09564239410051902

[21] A. Tukker, "Eight Types of Product-Service System: Eight Ways to Sustainability? Experiences from SusProNet," Business Strategy and the Environment, Vol. 13, No. 4, 2004, pp. 246-260. doi:10.1002/bse.414

[22] D. Miller, Q. Hope, R. Eisengstat, N. Foote and J. Galbraith, "The Problem of Solutions: Balancing Clients and Capabilities,” Business Horizons, Vol. 45 No. 2, 2002, pp. 312. doi:10.1016/S0007-6813(02)00181-7

[23] K. S. Powar, A. Beltagui and J. C. K. H. Riedel, "The PSO Triangle: Designing Product, Service and Organisation to Create Value," International Journal of Operations and Production Management, Vol. 29, No. 5, 2009, pp. 468-493. doi:10.1108/01443570910953595

[24] O. Mont, "Product-Service Systems: Panacea or Myth," Ph.D. Thesis, Lund University, Lund, 2004.

[25] D. J. Teece, G. Pisano and A. Shuen, "Dynamic Capabilities and Strategic Management,” Strategic Management Journal, Vol. 18, No. 7, 1997, pp. 509-533. doi:10.1002/(SICI)1097-0266(199708)18:7<509::AID-S MJ882>3.0.CO;2-Z

[26] J. C. Anderson and J. A. Narus, "Selectively Pursuing More of Your Customer's Business,” Sloan Management Review, 2003, pp. 42-49.

[27] A. Davies, “Are Firms Moving 'Downstream' into HighValue Services?” Imperial College Press, London, 2003.

[28] S. Brax and K. Jonsson, "Developing Integrated Solution Offerings for Remote Diagnostics; A Comparative Case Study of Two Manufacturers," International Journal of Operations \& Production Management, Vol. 29, No. 5, 2009, pp. 539-560. doi:10.1108/01443570910953621

[29] M. Kosaka, “Chi-No Seichou Model, a No Approach,” Sakai Hyono Ron-Sha Publication, 2010.

[30] S. L. Vargo and R. F. Lusch, "Service-Dominant Logic: What It Is, What It Is Not, What It Might Be,” In: R. F. Lusch and S. L. Vargo, Eds., The Service Dominant Logic of Marketing: Dialog, Debate and Directions, Sharpe, Armonk, 2006, pp. 43-56. 
[31] A. Lonnqvist and G. Schiuma, "Intellectual Capital and Service Productivity," International Journal of Service Technology and Management, Vol. 14, No. 4, 2010, pp. 303-309.

[32] C. Grönroos, “Adopting a Service Logic for Marketing,” Marketing Theory, Vol. 6, No. 3, 2006, pp. 317-333. doi:10.1177/1470593106066794

[33] A. Munos, "Service Delivery Systems, Services Marketing and Technologies," International Journal of Service Technology and Management, Vol. 3, No. 3, 2002, pp. 263-276. doi:10.1504/IJSTM.2002.001630

[34] C. K. Prahalad and V, Ramaswamy, "Co-Creating Unique Value with Customers,” Strategy and Leadership, Vol. 32, No. 3, 2004, pp. 4-9. doi:10.1243/09544054JEM858

[35] M. Kosaka and T. Yabutani, “A Consideration on Service Business Model for Saving Energy and Reduction of $\mathrm{CO}_{2}$
Emission Using Inverters,” IEEJ Transactions on Electronics, Information and Systems, Information and System, Vol. 129, No. 4, 2009, pp. 755-761. doi:10.1541/ieejeiss.129.755

[36] F. Rodrigues, V. Souza and J. Leitão, "Strategic Coopetition of Global Brands: A Game Theory Approach to 'Nike + iPod Sport Kit' Co-Branding," International Journal of Entrepreneurial Venturing, Vol. 3, No. 4, 2011, pp. 435-455.

[37] Toray Industries, Inc., "Forming the UNIQLO-Toray Strategic Partnership,” Toray Industries, Inc., Tokyo, 2006.

[38] E. K. Choi, "Paradigm Innovation through Strategic Collaboration between TOREY \& UNIQLO: Evolution of a New Fast Fashion Business Model,” Institute of Innovation Research Hitotshubashi Unversty, Tokyo, 2011. 